\title{
No Global Labor History without Africa: Reciprocal Comparison and Beyond
}

Karin Hofmeester, Jan Lucassen, Filipa Ribeiro da Silva

\begin{abstract}
This introduction explains why it is important to include the history of labor and labor relations in Africa in Global Labor History. It suggests that the approach of the Global Collaboratory on the History of Labour Relations 1500-2000 - with its taxonomy of labor relations - is a feasible method for applying this approach to the historiography on labor history in Africa. The introduction ends with an analysis of four case studies that are presented in this special section, with a specific focus on shifts in labor relations and how they could be explained.
\end{abstract}

Résumé: Cette introduction explique pourquoi serait-il important que d'inclure dans l'Histoire Globale du Travail - l'histoire du travail et les relations de travail en Afrique. Elle véhicule l'approche du projet "Pour une Collaboratoire Globale sur l'Histoire des Relations de Travail, 1500-2000." En particulier, ce projet propose une taxonomie des relations de travail comme instrument méthodologique, en replaçant celle-ci dans le cadre de l'historiographie de l'histoire du travail dans une perspective locale et mondialisée. L’introduction termine avec une analyse des cinq études de cas présentés dans cette section spéciale avec une attention portée aux changements survenus dans les relations de travail.

Bio-sketch: Karin Hofmeester is deputy director of research at the International Institute of Social History in Amsterdam and a professor at the University of Antwerp. She is the project manager of the Global Collaboratory on the History of Labour Relations in the period 1500-2000 and has published material on global labor 
history and global commodities. Contact: kho@iisg.nl; Jan Lucassen was director of research and senior researcher at the International Institute of Social History in Amsterdam, where he is now an honorary research fellow. Furthermore, he is emeritus professor at the Free University in Amsterdam. He has published widely on early modern and modern history of labor and migration, mainly of Western Europe, but also of India. Contact: jlu@iisg.nl; Filipa Ribeiro da Silva is assistant professor at the Department of History, University of Macau. Her research interests are Early Modern Economic and Social History, Maritime History, Portuguese and Dutch Overseas History and Iberian Inquisitions. She has published material on the Dutch and Portuguese in Western Africa and the Atlantic System, on labor migration to West Africa and on labor relations in Mozambique. Contact: fsilva@umac.mo

\section{Introduction $^{1}$}

This special section of History in Africa is dedicated to labor relations in Sub-Saharan Africa from 1500 to 2000 . The main aim of this collection is to foster a new methodological approach for the study of African Labor History in the pre-colonial, colonial and post-colonial periods and to place the history of labor in Africa back into Global Labor History. We will start with a brief reflection on the role of Global Labor History as provider of an understanding of the rise of modern society since 1500 and its labor force worldwide. This will be followed by a concise historiographical overview on Sub-Saharan African labor, based on a number of recent studies. Finally, we will discuss some major implications of including Africa in the Global Labor History Project, in general terms as well as based on the four case studies presented here.

\footnotetext{
${ }^{1}$ The authors wish to thank all the contributors to this special section - and Gareth Austin - for their helpful comments regarding this introduction.
} 
Global Labor History is the history of people who have built our modern world through their work - not just wage laborers, but also slaves, sharecroppers, housewives, the self-employed, and many other categories of workers that are all included in our taxonomy of labor relations (see page XX). It focuses on the labor relations of these people, as individuals but also as members of households, networks and other contexts. Global Labor History compares developments in several parts of the world and attempts to reveal major shifts and continuities as well as intercontinental connections and interactions. For various reasons it is very important to integrate the history of labor in Africa into Global Labor History: not only for the obvious sake of completeness, but also because specific labor relations and combinations of labor relations prevailed and still do so in various parts of Africa. They have to become part of our global analysis of labor or else its incompleteness not only affects the history of labor in Africa but also that of other parts of the world. The most obvious example is transatlantic slavery; writing a global history of labor is impossible without touching upon this topic. But there are more features of the history of labor that catch the eye, as will be explained below. As producing, trading and consuming continent with very old global links, Africa is very important when studying the interconnections between developments of labor relations worldwide over a longer period of time. To quote Frederick Cooper: "We need to remember how much Africa has been shaped by its connections to the rest of the world and how much the world as we know it has been shaped by the labor of Africans.",2

This special section, including the method it suggests for studying labor relations worldwide, and the four case studies it presents are the result of a project called the Global Collaboratory on the History of Labour Relations, 1500-2000. As a

\footnotetext{
${ }^{2}$ Frederick Cooper, "African Labor History," in: Jan Lucassen (ed.), Global Labour History. A State of the Art (Bern: Peter Lang, 2006), 91-116.
} 
general background of this special section, some information on the project is provided below.

\section{The Global Collaboratory on the History of Labour Relations, 1500-2000}

The International Institute of Social History (IISH) in Amsterdam coordinates the Global Collaboratory on the History of Labour Relations. ${ }^{3}$ First of all, it aims at making a worldwide inventory of all types of labor relations, in all their facets and combinations, in different parts of the world during five cross-sections in time: 1500, 1650, 1800, and 1900, as well as 1950, and 2000 for Africa. ${ }^{4}$ The second step is analyzing major shifts in labor relations by answering questions such as: when did a specific type of labor relation give way to another and how can we explain and connect these transitions in a global context? The project could only be set up with the cooperation of a large group of specialists who gather data on specific regions and cross-sections. These specialists meet during workshops, i.e. plenary workshops and workshops per region, such as Sub-Saharan Africa, the Ottoman Empire, the Lusophone world - which of course partly overlaps with Sub-Saharan Africa but also includes Portugal, Brazil, the Azores, and Macau and India. In addition, we work

\footnotetext{
${ }^{3}$ For more information on the history of the IISH please see: http://socialhistory.org/en/about/history for its mission see: http://socialhistory.org/en/mission ${ }^{4}$ This project has been made possible by generous grants from the Gerda Henkel Stiftung in Düsseldorf, the Netherlands Organization of Scientific Research (NWO) and the International Research Centre re: work of the Humboldt University in Berlin. We also wish to thank the Institut für Wirtschafts- und Sozialgeschichte (WISO) of the University of Vienna, where Josef Ehmer in particular has been a very important supporter; the Universidade Nova de Lisboa, where Raquel Varela helped us develop the Lusophone network; the Indian Council of Historical Research in Delhi, where Shireen Moosvi was a key figure; the University of Addis Ababa, where Shiferaw Bekele provided major support; and finally, the Netherlands Institute in Turkey, based in Istanbul, where the director, Fokke Gerritsen, gave us a very warm welcome.
} 
together closely in a collaboratory, an on-line laboratory that we use to share data, and discuss methodological aspects and other issues. ${ }^{5}$ All the participants create a dataset for their area and cross-section, and simultaneously describe the sources and methods used in a separate methodological paper. The datasets and methodological papers can be found on the Collaboratory website. ${ }^{6}$ To facilitate the combination and comparison of all datasets we developed a model database. The aim is to create a comprehensive dataset on labor relations worldwide. For this purpose, the members of the Collaboratory have developed an important innovative element for the project, namely a taxonomy of labor relations based on a set of definitions of labor relations (see appendix 1), which can be applied to the entire world and allows for interregional and worldwide comparisons.

In Europe, efforts to classify types of work date back to Classical Antiquity, ${ }^{7}$ and similar classifications may apply to other parts of the world - although sources, and especially academic research, are much rarer in these cases. ${ }^{8}$ In the past, these classifications concentrated on values related to different types of work: intellectual and manual, agricultural, industrial and commercial, work in the household and in public and the like.

Most systematic were the attempts of the authors of the French Encyclopédie, first published 1751-1772, from which follow all classifications in occupational censuses made in North Atlantic countries and their colonies as well as the

\footnotetext{
${ }^{5}$ For the Collaboratory, please see: https://collab.iisg.nl/web/labourrelations/about. ${ }^{6}$ https://collab.iisg.nl/web/labourrelations/results

${ }^{7}$ Catharina Lis and Hugo Soly, Worthy Efforts: Attitudes to Work and Workers in Pre-Industrial Europe (Leiden: Brill, 2012); see also the discussion about this book, which is forthcoming in a special issue of The Low Countries Journal of Social and Economic History 11-1 (2014).

${ }^{8}$ Karin Hofmeester and Christine Moll-Murata (eds.), International Review of Social History 56-1 (2011) (Special Issue: "The Joy and Pain of Work: Global Attitudes and Valuations, 1500-1650”).
} 
International Standard Classification of Occupations (ISCO). The latter was developed from the 1950s onwards by the International Labor Office (ILO), allowing for classification of occupational activities worldwide. Based on the ISCO, historians have developed a historical international classification of occupations (HISCO) combined with information on their tasks and duties in historical settings as well as images of the history of work. ${ }^{9}$

Whereas these classifications of types of work looked at the products made and services performed, such as primary production (agriculture, fisheries, mining) and the processing industry, others attempted to systematize work according to the different human relations involved. The oldest categorizations are the distinctions between master and servant and between slave owner and slave. In addition to these legal distinctions, the notion of social stratification and Karl Marx's notion - and that of others inspired by him - of class society were developed. Central to this line of thinking was the rise of the proletariat, i.e. the wage-dependent workers. As far as we know, the German scholar Werner Sombart (1863-1941) was the first one who attempted to apply this concept to the entire occupational population of a country (in this case the German Empire in 1905). ${ }^{10}$ Subsequently, sociologists and historians tried to apply these categories to the entire population of Europe (except Russia) for the last five centuries. ${ }^{11}$

Ethnographers, geographers and archeologists - some of whom also refer to Karl Marx - have pointed out, and sometimes even emphasized, the differences between labor relations in market economies in the West and those in the rest of the

\footnotetext{
${ }^{9}$ http://socialhistory.org/en/projects/hisco-history-work

${ }^{10}$ Werner Sombart, Das Proletariat. Bilder und Studien (Frankfurt am Main: Rütten \& Loening, 1906).

${ }^{11}$ Charles Tilly, "Demographic Origins of the European Proletariat," in: David Levine (ed.), Proletarianization and Family History (Orlando: Academic Press 1984), 1-85.
} 
world. ${ }^{12}$ Finally, irrespective of time and place, occupational census takers, sociologists, and historians have increasingly struggled with the definitions of work, thereby having been influenced by the emerging feminist movements that stressed the importance of the often unnoticed work of women and children. A most encompassing definition has been provided by the sociologists Charles Tilly and Chris Tilly: "Work includes any human effort adding use value to goods and services. (...) Only a prejudice bred by Western capitalism and its industrial labor markets fixes on strenuous effort expended for money payment outside the home as 'real work', relegating other efforts to amusement, crime, and mere housekeeping."13

All these lines of thinking have inspired the members of the Collaboratory to develop a new encompassing classification of labor relations, ${ }^{14}$ aimed at replacing previous schemes so as to enable long-term global comparisons. This classification of labor relations claims a much wider validity than the traditional occupational censuses as it is supposed to cover the whole world from 1500, and in principle also from earlier periods. At the same time, it pays tribute to a long historical pedigree of ideas and it intends to offer an analytical instrument for comparing labor relations globally.

\footnotetext{
${ }^{12}$ Jan Lucassen, Outlines of a History of Labour (IISH Research Papers 51, 2013), also available at http://socialhistory.org/en/publications/outlines-history-labour (commenting on Weber, Polanyi, Chayanov, and others).

${ }^{13}$ Charles Tilly and Chris Tilly, Work under Capitalism (Boulder CO: Westview Press, 1998), 22.

${ }^{14}$ Historically and linguistically the distinction between work and labor - just as between oeuvre and travail, Werk and Arbeit, and the like - refers to the distinction between creative activities versus strenuous activities. However, in the practice of labor history the distinction is different: labor is less general than work as the term refers to a specific type of work, mostly reserved for market economies, where it may be free labor or forced labor. Strictly speaking, we should therefore speak of work relations, but this terminology is rather uncommon, whereas labor relations is a more common term in the field of historical studies on work and labor.
} 
As a starting point for examining each geographical unit and cross-section and as a result of each dataset, we take the entire population and subsequently determine which segment of the population is generally unemployed, and consequently, which segment is working in which type of labor relation. Another consideration from the outset is the household size. Taking the household as the basic unit in which both the major parts of income and consumption are shared, we distinguish between heads of households and subsidiary kin and others who are considered part of the household. Basic ideas about gender, age and sexuality determine the tasks attributed to the different members of the household. ${ }^{15}$ For these two reasons, demography is a very important ancillary of the project, which is also reflected in the articles that make up this special section.

The logic behind the classification of the total population data may be summarized as follows. First, it distinguishes between those who are able or unable to work (the latter are included in our taxonomy in the category non-working, see appendix 1). This has at least two advantages. Firstly, it forces the researcher to be aware of what work is. Secondly, it includes the entire population, explicitly also taking into account the working women and children. As a consequence, in the dayto-day practice of historical research it compels scholars to test the demographic logic of their results as all categories combined together should equal the total population. ${ }^{16}$ In addition, it provides a basic critique of virtually all occupational censuses, which systematically under-recorded female work and work in the household in general.

Next, the classification distinguishes between three different principles upon which societies organize the exchange of goods and services including work. Often,

\footnotetext{
${ }^{15}$ See: Jan Kok, “The Family Factor in Migration Decisions," in: Jan Lucassen, Leo Lucassen and Patrick Manning (eds.), Migration History in World History. Multidisciplinary Approaches (Leiden: Brill, 2011), 215-250.

${ }^{16}$ For a definition of what work is, see Charles Tilly and Chris Tilly, Work under Capitalism, chapter 2.
} 
but not necessarily, these principles coincide with different types of societies, while a society is largely dominated by one of the principles. ${ }^{17}$ These principles are reciprocity, work done for the other members of the same household or community; tribute giving, work based on obligations vis-à-vis the polity, which owns labor; and market exchange in which labor is commodified, i.e. where workers sell their means of production or the products of their work and where unfree workers are sold and bought.

\section{Taxonomy of labor relations}

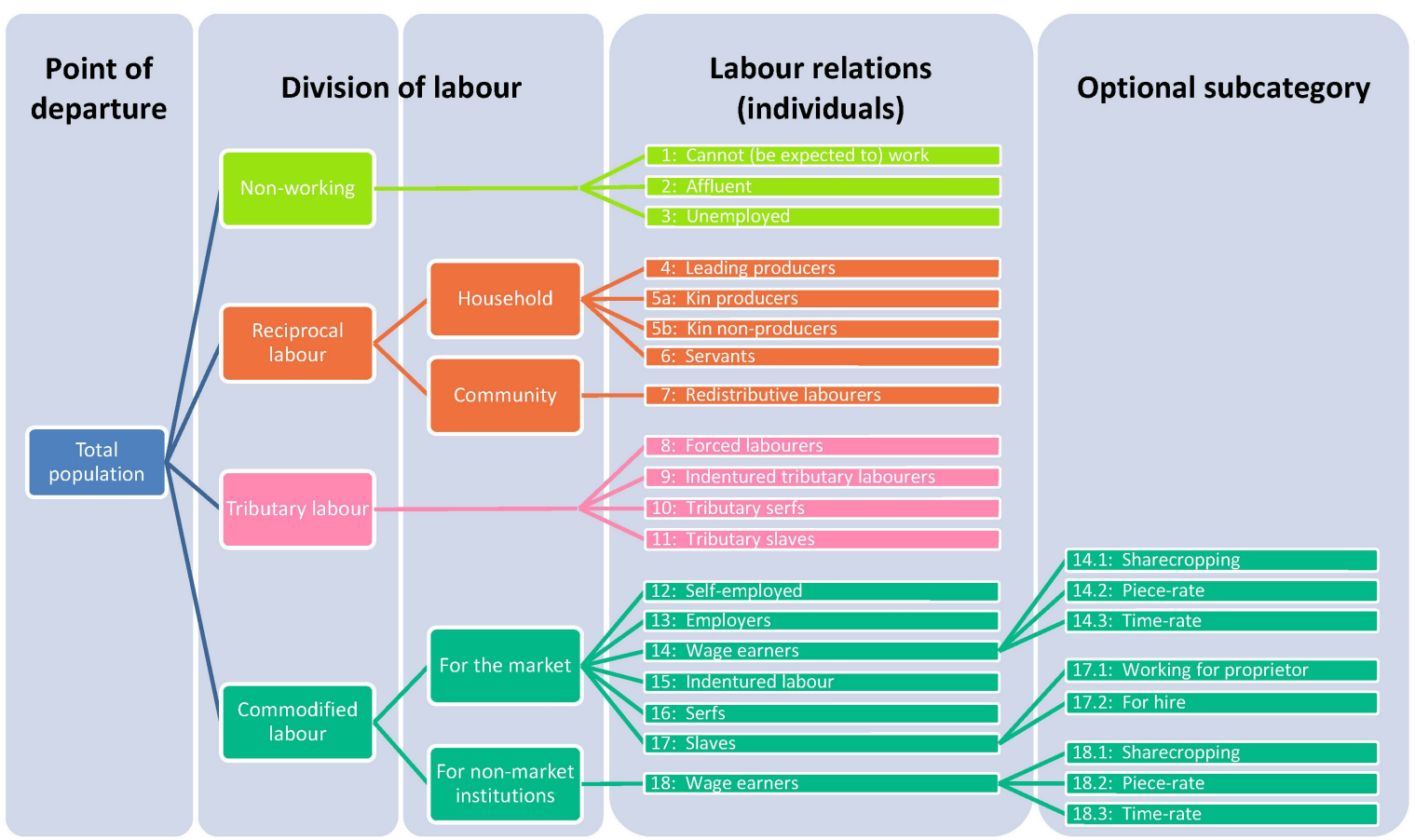

For the past five hundred years, in most parts of the world reciprocal labor has no longer been the most important category. For example, in the case of South Asia, it has been remarked that self-sufficiency never existed during this period. Basic foodstuffs, such as salt, and materials for tools and weapons (e.g., iron), were acquired

\footnotetext{
${ }^{17}$ We stress the term dominate because since the introduction of agriculture, all societies combine two or more of these main organizational principles. Think of reciprocal labor in the household, performed by spouses (labor relation $5 \mathrm{~b}$ ) in a society dominated by commodified labor.
} 
through barter or monetary transactions even in tribal societies, which by 1500 were only marginally exposed to market production. ${ }^{18}$ This is true even if we concede that self-sufficiency according to our understanding - which is included in our taxonomy's labor relations 4, 5a, and 6-can include small-scale market transactions that aim at sustaining households rather than accumulating capital by way of profiting from exchange value. ${ }^{19}$

All other more refined distinctions fall within these four main categories in our taxonomy's definitions: labor relations 1-3 for non-working, labor relations 4-6 for reciprocal, labor relations 7-11 for tributary, and labor relations 12-18 for commodified labor. These categories are based on various considerations, such as the entities that organize labor (households, communities or polities), the levels of freedom and unfreedom, methods of remuneration, etc. These sub-categories will be explained in detail below. The Collaboratory fully recognizes the fact that persons may experience different labor relations simultaneously, such as serfs who are allowed to perform wage labor during part of the year. In those cases, the researcher may attribute the first labor relation to the main activity (as defined by hours spent) and the second or even third labor relation to the subsidiary activity. So far, research has

\footnotetext{
${ }^{18}$ According to Amalendu Guha, “The Medieval Economy of Assam," in: Tapan Raychaudhuri and Irfan Habib (eds.), The Cambridge Economic History of India, volume 1: c. 1200 - c. 1750 (Cambridge: Cambridge University Press, 1982), PLEASE ADD PAGE NUMBERS, 478-505, 487: "fVfillage self-sufficiency in a total sense was a myth," even for the relatively remote sixteenth- and seventeenth-century Assam.

${ }^{19}$ Marcel van der Linden, Workers of the World. Essays toward a Global Labor History (Leiden: Brill, 2008), 315-316, referring to Gerald A. Cohen, Karl Marx's Theory of History: A Defence (Oxford:
} Oxford University Press, 1978). See also: Akira Hayami, Osamu Saitô and Ronald P. Toby (eds.), The Economic History of Japan, 1600-1990, volume 1: Emergence of Economic Society in Japan, 1600-1859

(Oxford: Oxford University Press, 2004), who argue in a similar sense for a broader concept of selfsufficiency that allows for market production as long as accumulation is not the basic goal of such transactions. 
shown that shifts in labor relations mostly take the form of shifts in such combinations, especially in the short run.

We would like to stress that the classification of labor relations is not the nec plus ultra of labor history, it is the first but very necessary step. The next steps include analytically connecting the previous step to questions relating to the remuneration of work - including the standard of living and wages - and to individual as well as collective actions (from petitions to strikes and social revolutions) in order to maintain or improve remuneration of work. However, these are not the objective of this current section..$^{20}$

In what follows we will focus on the implications of Global Labor History for the history of labor in Africa, and vice versa, and more specifically on the first Collaboratory results for Africa. However, first we will take a closer look at the historiography of labor history in Africa and its global perspective.

\section{The Historiography of Labor in Africa and the Global Perspective}

In his 2002 overview of African labor history, Frederick Cooper describes a growing awareness among scholars during the late 1970s of Africa's deviation from the

\footnotetext{
${ }^{20}$ To name just a few, but important publications on this topic: Anthony G. Hopkins, "The Lagos Strike of 1897: An Exploration in Nigerian Labour History," Past and Present 35 (1966), 133-155, which was reprinted in: Robin Cohen, Peter Gutkind and Phyllis Brazier (eds.), Peasants and Proletarians: the Struggles of Third World Workers (New York: Monthly Review Press, 1979), 87-106; the classic Charles Van Onselen, Chibaro: African Mine Labour in Southern Rhodesia, 1900-1933 (London: Pluto Press, 1976); Charles Van Onselen, The Seed is Mine: the Life of Kas Maine, a South African Sharecropper, 1894-1985 (New York: Hill and Wang, 1996); Ian Phimister, Wangi Kolia: Coal, Capital, and Labour in Colonial Zimbabwe, 1894-1954 (Harare: Baobab Books, 1994); Jeanne Penvenne, African Workers and Colonial Racism: Mozambican Strategies and Struggles in Lourenço Marques, 1877-1962
}

(Portsmouth NH: Heinemann, 1995). 
standard trajectory of proletarianization, which is supposed to lead to the development of a working class of wage laborers. ${ }^{21}$ The unraveling of the so-called "classic narrative of proletarianization" took place in other parts of the world as well, but in Africa, the study of the development of a class of wage laborers had a longer history, starting in the late colonial period. Europeans studied the working classes intensively to signal possible political unrest in an early stage and to help create a modern workforce by, for instance, controlling and containing the migration of workers from rural areas to cities. ${ }^{22}$ The proletarianization trajectory, which was studied so intensively in the period from the 1950s to the end of the 1970s, was based on a Eurocentric view that did not fit the multifaceted developments in Sub-Saharan Africa. Cooper suggests that instead of looking at a single model of capitalist development, scholars should look for specific patterns, and rather than comparing two areas and pointing at a supposed lack of a phenomenon in one area, interactions should be analyzed. ${ }^{23}$ Various studies on wage workers in the extraction industries, railroads and ocean docks, as well as unfree labor in cash crop production mention the global interactions of the work performed. However, in the 1980s and 1990s, many scholars shifted their attention to women, rural populations and to what is often called the informal sector, as well as to micro-histories of workers and work in relation to gender, race and ethnicity, leaving global interactions aside. This development was paralleled by a political reality in which organized labor lost much of its influence, not only in Africa but in other parts of the world as well. This paradigm change led to innovative approaches and informative studies from a local African perspective, but it did not provide insights into the historical connections between

\footnotetext{
${ }^{21}$ For an overview of the historiography of labor and a general overview of the African working class see: Bill Freund, The African Worker (Cambridge: Cambridge University Press, 1988).

${ }^{22}$ Lynn Schler, Louise Bethlehem and Galia Sabar, "Rethinking Labour in Africa, Past and Present," African Identities 7-3 (2007), 287-298, 287-288.

${ }^{23}$ Cooper, "African Labor History," 93.
} 
local and global developments. "A willingness to focus back and forth from the intimacy and complexity of relationships in specific places and their connections to distant places and long processes of change" is still needed. ${ }^{24}$

The history of slave trade and of slavery is the quintessential history of interconnections between distant places and groups of people and as such, it is often analyzed as part of global history. ${ }^{25}$ In these analyses, the history of wage workers and of slaves is often seen as two different histories rather than two parts of one global history of work. In the last fifty years, a growing interest in the study of slave trade and slavery has helped to expand our understanding regarding the links between the history of labor in Africa and the history of labor in other parts of the world. The slave trade developed in three directions, namely the trans-Sahara trade, the slave trade to the Middle East, and, finally, the trans-Atlantic trade, which has received the most attention. ${ }^{26}$ This scholarship has greatly increased our knowledge regarding the number of enslaved Africans transported from Africa to the Americas and the greater

\footnotetext{
${ }^{24}$ Cooper, "African Labor History," 94.

${ }^{25}$ An essential book on slavery remains: Paul E. Lovejoy, Transformations in Slavery: A History of Slavery in Africa (Cambridge: Cambridge University Press, 2013).

${ }^{26}$ For proportions see: Patrick Manning, Slavery and African Life: Occidental, Oriental, and African Slave Trades (New York: Cambridge University Press, 1990). For guestimates for numbers in the transSaharan slave trade see: Ralph A. Austen, “The Trans-Saharan Slave Trade: A Tentative Census,” in: Henry A. Gemery and Jan S. Hogendorn (eds.), The Uncommon Market; Essays in the Economic History of the Atlantic Slave Trade (New York: Academic Press, 1979), 77-106; Ralph A. Austen, "The Mediterranean Islamic Slave Trade out of Africa: A Tentative Census," in: Elizabeth Savage (ed.), The Human Commodity: Perspectives on the Trans-Saharan Slave Trade (London: Frank Cass, 1992), 214 224; Ralph A. Austen, "The 19th Century Islamic Slave Trade from East Africa (Swahili and Red Sea Coasts): A Tentative Census," Slavery and Abolition: A Journal of Slave and Post-Slave Studies 9-3 (1988), 21-44. Also see: Indrani Chatterjee and Richard M. Eaton (eds.) Slavery and South Asian History (Bloomington: Indiana University Press 2006).
} 
Indian Ocean, ${ }^{27}$ and the conditions under which they were displaced and coerced to work and live in their host societies. ${ }^{28} \mathrm{Also}$, it has increased our knowledge regarding the characteristics of the slave trading business and the economic dynamics of demand and supply in several slave labor markets across the world. ${ }^{29}$ In the specific

${ }^{27}$ Philip D. Curtin, The Atlantic Slave Trade: A Census (Madison WI: University of Wisconsin, 1969). David Eltis, Stephen D. Behrendt, David Richardson and Herbert S. Klein, The Transatlantic Slave Trade 1527-1867: A Database on CD-Rom (New York: Cambridge University Press, 1999); Voyages: The Trans-Atlantic Slave Trade Database: http://www.slavevoyages.org; David Eltis and David Richardson (eds.), Extending the Frontiers: Essays on the New Transatlantic Slave Trade Database (New Haven: Yale University Press, 2008). David Eltis and David Richardson, Atlas of the Transatlantic Slave Trade (New Haven CT: Yale University Press, 2010); Gwyn R. Campbell (ed.), The Structure of Slavery in Indian Ocean Africa and Asia (London: Frank Cass, 2004); Richard C. Allen, Slaves, Freedmen, and Indentured Laborers in Colonial Mauritius (Cambridge: Cambridge University Press, 2006); Edward A. Alpers, Ivory \& Slaves in East Central Africa (London: Heinemann, 1975).

${ }^{28}$ See among others: José C. Curto and Renée Soulodre-La France (eds.), Africa and the Americas: Interconnections during the Slave Trade (Trenton: Africa World Press, 2005); Laird W. Bergad, Slavery and the Demographic and Economic History of Minas Gerais, Brazil, 1720-1888 (Cambridge: Cambridge University Press, 1999); Linda M. Heywood (ed.), Central Africans and Cultural Transformations in the American Diaspora (Cambridge: Cambridge University Press, 2002); Joseph E. Inikori and Stanley L. Engerman (eds.), The Atlantic Slave Trade: Effects on Economies, Societies, and Peoples in Africa, the Americas, and Europe (Durham: Duke University Press, 1992).

${ }^{29}$ See among others: Paul E. Lovejoy and David Richardson, "The Business of Slaving: Pawnship in Western Africa, c. 1600-1810," The Journal of African History 42-1 (2001), 67-89; Paul E. Lovejoy and Toyin Falola (eds.), Pawnship, Slavery, and Colonialism in Africa (Trenton NJ: Africa World Press, 2003); Joseph C. Miller, "Capitalism and Slaving: The Financial and Commercial Organization of the Angolan Slave Trade, According to the Accounts of Antonio Coelho Guerreiro (1684-1692)," The International Journal of African Historical Studies 17-1 (1984), 1-56; Joseph C. Miller, Way of Death. Merchant Capitalism and the Angolan Slave Trade, 1730-1830 (Madison WI: University of Wisconsin Press, 1988); David W. Galenson, Traders, Planters, and Slaves: Market Behavior in Early English America (Cambridge: Cambridge University Press, 1986); David Eltis, Frank D. Lewis and David Richardson, "Slave Prices, the African Slave Trade and Productivity in the Caribbean, 1674-1807," Economic 
case of Africa, the study of enslaved workers has also opened a long-standing debate about the role and impact of slave trade, slavery, and abolition on the continent's economic and social development, or lack thereof, ${ }^{30}$ and on the contribution of enslaved labor to the enrichment of Europe and other parts of the world. ${ }^{31}$

However, in these analyses, the history of wage workers and of slaves in Africa and elsewhere are often seen as two different histories rather than two parts of one

History Review 584 (2005), 673-700; Manolo Florentino, “The Slave Trade, Colonial Market, and Slave Families in Rio de Janeiro, ca. 1790-ca. 1830," in: David Eltis and David Richardson (eds.), Extending the Frontiers: Essays in the New Transatlantic Slave Trade Database (New Haven: Yale University Press, 2008), 275-312.

${ }^{30}$ On this debate see among others: Anthony G. Hopkins, An Economic History of West Africa (London: Longman 1973), 78-123; Walter Rodney, How Europe Underdeveloped Africa (Washington: Howard University Press, 1974). Walter Rodney, "Gold and Slaves on the Gold Coast, “ Transactions of the Historical Society of Ghana 10 (1969), 13-28. Conversely, see: Joseph E. Inikori, “The Economic Impact of the 1807 British Abolition of the Transatlantic Slave Trade," in: Toyin Falola and Matt D. Childs (eds.), The Changing Worlds of Atlantic Africa: Essays in Honor of Robin Law (Durham: Carolina Academic Press, 2009), 163-182; Nathan Nunn, "Historical Legacies: A Model Linking Africa's Past to its Current Underdevelopment," Journal of Development Studies 83-1 (2007), 157-175; Nathan Nunn, “The Long Term Effects of Africa's Slave Trades," Quarterly Journal of Economics 123-1 (2008), 139-176. For a critique see: Gareth Austin, "The 'Reversal of Fortune’ Thesis and the Compression of History: Perspectives from African and Comparative Economic History," Journal of International Development 20-8 (2008), 996-1027.

${ }^{31}$ On this debate, see among others: Eric Williams, Capitalism and Slavery (Chapel Hill: University of North Carolina Press, 1994 [1944]); Joseph E. Inikori, Africans and the Industrial Revolution in England: A Study in International Trade and Development (Cambridge: Cambridge University Press, 2002). Patrick O’Brien, "European Economic Development: the Contribution of the Periphery," Economic History Review 35-1 (1982), 1-18. Kevin H. O’Rourke, Leandro Prados de la Escosura and Guillame Daudin, "Trade and Empire," in: Stephen Broadberry and Kevin H. O’Rourke (eds.), The Cambridge Economic History of Modern Europe, volume, 1700-1870 (Cambridge: Cambridge University Press, 2010), 96-121. 
single local, regional and global history of work. Recognition of the latter point also helps us to understand the kind of labor relations that developed after the abolition of the slave trade and slavery. Often, ex-slaves would combine various types of labor relations, such as forms of cash-crop production, self-subsistence production and wage labor; whereas plantation owners and colonial states would resort to the massive recruitment of indentured workers, forced laborers and the introduction of systems of forced cultivation. ${ }^{32}$ These combinations differed from region to region and gender roles, kinship networks, migration patterns all determined different solutions. ${ }^{33}$

As Lynn Schler, Louise Bethlehem and Galia Sabar have shown in their 2007 overview, the next development in the historiography of labor in Africa is the postcolonial critical studies. In the last decade of the twentieth and the first decade of the twenty-first century, these studies have led to a focus on identities and experiences and on discourse, subjectivity and culture. ${ }^{34}$ This perspective raised an increased attention to the local perception of the present globalizing world and to the effect this had on identities in Africa. However, the effects of global connections on the material conditions of labor and labor relations still requires further research. Today, the

\footnotetext{
${ }^{32}$ See among others: Robin Law (ed.), From Slave Trade to "Legitimate" Commerce. The Commercial Transition in Nineteenth-Century West Africa (Cambridge: Cambridge University Press, 1995); Gareth Austin, "Cash Crops and Freedom: Export Agriculture and the Decline of Slavery in Colonial West Africa," International Review of Social History 54-1 (2009), 1-37; Suzanne Miers and Richard Roberts (eds.), The End of Slavery in Africa (Madison WI: Wisconsin University Press, 1988); Suzanne Miers and Martin A. Klein (eds.), Slavery and Colonial Rule in Africa (London: Frank Cass, 1999); Babacar Fall, Le travail forcé en Afrique-Occidentale française, 1900-1946 (Paris: Karthala, 1993); David Northrup, Beyond the Bend in the River: African Labor in Eastern Zaire, 1865-1940 (Athens OH: Ohio University Center of International Studies, 1988); Osumaka Likaka, Rural Society and Cotton in Colonial Zaire (Madison WI: University of Wisconsin Press, 1997).

${ }^{33}$ Cooper, "African Labor History," 102.

${ }^{34}$ Schler et al, "Rethinking Labour in Africa," 288.
} 
general call is for a return to materiality, "the nitty-gritty of labour" as Frederick Cooper has called it. ${ }^{35}$ For some, this need for materiality is determined by the urge to understand African encounters with globalization, while others question the supposed unifying power of globalization. ${ }^{36}$ Why is it so difficult to understand the encounters of Africa with globalization? For some, neglect plays a role as African labor did not fit the grand narrative of globalization. "One can almost hear the sound of Sub-Saharan Africa sliding off the world map," Susan George stated in 1993. ${ }^{37}$ For others, like Megan Vaughan, the supposed uniformity of globalization clearly does not fit the uneven impact it had and still has on Africa and is a hindering factor when we want to link Africa with the birth of the modern world. ${ }^{38}$

In the historiography of labor in South Africa there is a strong tendency to see the developments in various parts of Africa as exceptional. Again there is a parallel with the actual political situation. Nowhere else in Sub-Saharan Africa did a group of workers develop that looked more like a classic proletariat in the Eurocentric ${ }^{39}$ sense than in South Africa and it was intensively and impressively studied as such. Alongside this trend, there exists a long tradition of analyzing the strong, politicized labor movement that played an important role in the struggle against Apartheid. As

${ }^{35}$ Frederick Cooper, "Back to Work: Categories, Boundaries and Connections in the Study of Labour," in: Peter Alexander and Rick Halpern (eds.), Racializing Class, Classifying Race (London: Macmillan, 2000), 213-235, 213.

${ }^{36}$ For an understanding of the encounter with globalization see Schler et al, "Rethinking Labour," 292. For a critique of the concept's utility for understanding global linkages see: Frederick Cooper, "What is the Concept of Globalization Good For? An African Historian's Perspective," African Affairs 100 (2001), 193-213.

${ }^{37}$ Quoted in Schler et al, "Rethinking Labour," 291.

${ }^{38}$ Megan Vaughan, "Africa and the Birth of the Modern World," Transactions of the Royal Historical Society, Sixth Series 16 (2006), 143-162, 161.

${ }^{39}$ Ironically, but not coincidentally, the category of workers that was most proletarianized was the South African poor in the early twentieth century. 
the overviews of Philip Bonner, Jonathan Hyslop and Lucien van der Walt from 2007, and of Bill Freund from 2013 have shown, in time, the historiography of labor in Southern and South Africa has become very rich, including important notions of working-class culture. ${ }^{40}$ Still, historiography often emphasized organized labor and proletarianized labor in South Africa as an isolated issue. Only in the last few years, as Freund shows, has the influence of globalization on labor and the impact of the precariousness of work on the gender division of labor been studied. Bonner, Hyslop and Van der Walt demonstrate that comparative studies, looking at urbanization and cheap mine labor in South Africa and India for example, show how remarkable the similarities can be and how important it is to not just compare colonial policies but also pre-colonial societies. ${ }^{41}$ They conclude their introduction with an urge for a combination of regional and transnational approaches and for situating South Africa in southern Africa, and southern Africa in the larger world.

If proletarianization and globalization both seem like concepts that are either too Eurocentric or too general to be applied to labor in Africa, how then can we connect the history of labor in Africa with the history of labor elsewhere in the world? Gareth Austin has suggested the procedure of reciprocal comparison, i.e. not only asking why labor in Africa is not more like labor in Europe, but also why labor in Europe is not more like labor in Africa. For these kinds of comparisons it seems vital to develop models for Africa and to try their applicability elsewhere. ${ }^{42}$ To develop these models,

\footnotetext{
${ }^{40}$ Philip Bonner, Jonathan Hyslop and Lucien van der Walt, "Rethinking Worlds of Labour: Southern African Labour History in International Context," African Studies 6-2/3 (2007), 137-168; Bill Freund, "Labour Studies and Labour History in South Africa: Perspectives from the Apartheid Era and After," International Review of Social History 58-3 (2013), 493-519.

${ }^{41}$ Bonner, Hyslop and Van der Walt, "Rethinking Worlds of Labour," 142.

${ }^{42}$ Gareth Austin, "Reciprocal Comparison and African History: Tackling Conceptual Eurocentrism in the Study of Africa's Economic Past," African Studies Review 50-3 (2007), 1-28, 10. The term "reciprocal comparison" is borrowed from Kenneth Pomeranz.
} 
some generalizations about parts of Africa, in the very least, should be made.

"Important though it is to recognize local differences, it is essential not to be disabled by it," to quote Austin. ${ }^{43}$ Austin's article focuses on the economic history of Africa. However, his inspiring examples of work done in various disciplines on specific elements of economic history in Africa - including agriculture, property rights, the social relations of production, the role of the state, and commercial institutions in regulating the labor market - are relevant not only to the study of long-term economic developments, but also to labor relation developments in Africa and in other parts of the world. Our intensive discussions about the taxonomy of labor relations - which undoubtedly initially developed from a Eurocentric perspective - and the final integrated approaches are perhaps one step in this direction.

Reciprocal comparison is also discussed in a working paper by the very active African Economic History Network, which stresses various elements of a comparative African economic history that are also very relevant to the history of labor, such as for population studies, labor costs, wages and prices, labor market institutions, etc. ${ }^{44}$

\section{What Does this Exercise Teach Us? First Results and Pathways for Further Research}

The Collaboratory was established approximately five years ago and its first contributions focused mainly on parts of Eurasia. Later, studies on other world regions were added, and finally, Africa also became part of the Collaboratory. This

\footnotetext{
${ }^{43}$ Austin, "Reciprocal Comparison," 11.

${ }^{44}$ Morten Jerven, Gareth Austin, Erik Green, Chibuike Uche, Ewout Frankema, Johan Fourie, Joseph E. Inikori, Alexander Moradi and Ellen Hillbom, "Moving Forward in African Economic History: Bridging the Gap Between Methods and Sources," African Economic History Working Paper Series 1 (2012), see: http://www.aehnetwork.org/wp-content/uploads/2012/05/AEHN-WP-1.pdf
} 
was only made possible through the setup of a network of Africa specialists and greatly enhanced by the organization of four main meetings since 2009. A special fifth workshop has been organized on archaeology and labor relations in Africa. ${ }^{45}$ During these workshops, we intensively discussed the setup of the project - including the taxonomy and definitions of various labor relations - in a clear effort to refine the analytical grid that the project uses and to make some adjustments to the benchmarks that were initially adopted. In the sequence of these meetings and in collaboration with the Africa specialists, we also decided to include an additional cross-section for the study of labor relations in Africa, namely the 1950 benchmark. The reason for this was that developments in the continent's labor relations during European colonial rule evolved very quickly in various regions during the first half of the twentieth century, and political circumstances often led to the execution of the first modern census around that period.

More than any other group of specialists, the Africanists have challenged us to explicitly explain the rationale behind the taxonomy. After long and fruitful discussions, much of the taxonomy also seemed to be applicable for Africa, but the interaction during these discussions also led to changes in the taxonomy. We have adapted the taxonomy for the African historical reality as captured in the data: for example, persons working under labor relation 17 (see the Taxonomy on page XX

\footnotetext{
${ }^{45}$ For the names of all the members of the Collaboratory, including the members of the Africa network, please see: https://collab.iisg.nl/c/document_library/get_file?p_l_id=273223\&folderId=277142\&name=DLF E-144108.pdf. The first pioneering workshop was organized on 6-7 November 2009 at the re:work Institute in Berlin; the second workshop was held on 7-8 April 2011 at the IISH in Amsterdam, the third workshop was held on 13-15 January 2012 at the University of Addis Ababa (with the help of the University and especially of Shiferaw Bekele), and the fourth workshop was held on 12-13 October 2012 at the IISH in Amsterdam. A special workshop on archeology and labor relations in Africa was held on 24-25 June 2013 in Estoril (Portugal).
} 
and the definitions in Appendix 1) are now called slaves instead of chattel slaves, which is a very specific form of slavery; labor relation 6 came to include a specific type of domestic slavery and we have stressed the importance of the gender of slaves as it can determine the status of the next generation. In addition, more than any other place in the world, Sub-Saharan Africa has recently experienced shifts in political borders. Consequently, focusing on cross-border regions seemed appropriate as well as focusing on smaller areas with regard to earlier cross-sections - where we have to rely on archaeology and historical linguistics.

The cases in this special section include mainland Tanganyika, ca. 1500-1900 by Paul Lane; Tanzania 1800-2000 by Karin Pallaver; Zimbabwe 1900-2000 by Rory Pilossof; Angola 1800-2000 by Jelmer Vos. These cases cover regions with strong interactions with internal and external markets. They can demonstrate the impact of connections with the global economy on the African labor markets and economies, as well as the impact of modern European colonization, decolonization and African independence processes on labor and labor relations. A comparison of these cases with cases from other parts of the world has already been examined in the framework of our Collaboratory and its taxonomy. It has highlighted important regional and worldwide differences in three main aspects: (1) the gendered division of labor; (2) the timing and geographical spread of shifts between reciprocal labor in self-sufficient societies (labor relations 4, 5a and 6) and tributary (idem 7-11) and commodified labor (idem 12-18) - with an especially striking durability of subsistence agriculture in various parts of the world; (3) the shifts between free and unfree labor in commodified societies. Here we can only very briefly elaborate upon these issues, but we hope that in the future they will receive more attention.

Already early on in history, outside observers have implicitly or explicitly stressed the laziness of African men in comparison to their own societies. Klas 
Rönnbäck's article elsewhere in this volume clearly demonstrates this. Though Rönnbäck only carefully states that there might be a gender aspect to the stereotype, various observers have been struck by the productive activities of African women in the fields, in the trade of field products and in trade in general. Willem Bosman, who came to the Gold Coast in 1688 and spent fourteen years there, has remarked that women worked extremely hard in farming everywhere. ${ }^{46}$ Modern research has confirmed this observation as far as hard working women are concerned. In precolonial nineteenth-century Asante, the basic distinction was that women did everything related to reproduction in the broadest sense of the word - such as food crop growing (with the exception of clearing the forest), child rearing and food preparation - while men concentrated on extra-subsistence activities. ${ }^{47}$ This is in line with Ester Boserup's famous book, though her depiction does not fit in everywhere. ${ }^{48}$ With regard to nineteenth-century Angola, Jelmer Vos concludes that whereas women were responsible for managing crops and the household, "men in rural society devoted most of their time to tending tree crops, hunting and fishing, building and maintaining homes, and the production of cloth, agricultural tools and weapons." ${ }^{49}$ The full explanation for the reasons behind this remarkable gendered division of labor lies beyond the scope of this introduction. On the one hand, it might be suggested that the more recent shift from hunting/gathering to agriculture in certain parts of Africa may be one explanation, while the increasing importance of warfare, the capturing of slaves (see below) and the skewed sex ratios of exported slaves have also

\footnotetext{
${ }^{46}$ Willem Bosman, A New and Accurate Description of the Coast of Guinea, Divided into the Gold, the Slave, and the Ivory Coasts (London: J.P. Knapton, 1705), 199-200.

${ }^{47}$ Gareth Austin, Labour, Land and Capital in Ghana: From Slavery to Free Labour in Asante, 1807-1956 (Rochester: University of Rochester Press, 2005).

${ }^{48}$ Ester Boserup, Women's Role in Economic Development (London: Earthscan, 2007).

${ }^{49}$ See Jelmer Vos in this special section as well as Rory Pilossof, who argues that the high bride price is evidence of the estimation of the productive power of women.
} 
played a role in the changing gender division of labor. ${ }^{50}$ On the other hand, one might argue that the productive activities of women also enabled easier labor migration of men and protracted split households. ${ }^{51}$

It is clear that before the advent of the Europeans, the continent was not exclusively dominated by reciprocal labor in self-sufficient societies. However, it is less clear where and when precisely these societies gradually started to develop forms of tributary or commodified labor, in all kinds of combinations. Yet, this development is crucial for scholars who wish to apply the taxonomy of the Collaboratory to concrete cases. A certain surplus is needed to allow for the emergence of tributary polities, not only to enable a higher standard of living and conspicuous consumption for the elites, but also to maintain the logistics involved in assigning labor tasks, collecting its products and redistributing them. The history of political systems in Africa will have to be one of the basic guidelines for the modern labor historian as this will help us explain the spread of various forms of labor relations. During the period of the Atlantic system's development, land was generally abundant and labor was scarce in Africa. Therefore, it was relatively easy to physically escape exploiters by migrating to another area, the exit option as Frederick Cooper has called it. "There were a few places with the resources for prosperity, but many places with adequate resources for survival, and corporate kinship structures made mobility into a collective process. ${ }^{\prime 52}$ However, this observation should be differentiated over time and space.

\footnotetext{
${ }^{50}$ Elias Mandala, "Capitalism, Kinship and Gender in the Lower Tchiri (Shire) Valley of Malawi, 1860-1960: An Alternative Theoretical Framework," African Economic History 13 (1984), 137-169. ${ }^{51}$ This is suggested by the contribution of Rory Pilossof.

${ }^{52}$ Cooper, "African Labor History," 96. He, of course, refers to Albert O. Hirschman, Exit, Voice, and Loyalty: Responses to Decline in Firms, Organizations, and States (Cambridge MA: Harvard University Press, 1970). Cooper's interpretation of the exit option should not be confused with the notion of exit option, suggested in the 1970s by development theoreticians, that refers to staying on the spot
} 
As the slave trade intensified, people eloping from their own society increasingly ran the risk of being captured and turned into slaves. This exit option was not only determined by geography, but also by social factors, such as extensive kinship ties, trading diasporas and religious networks, which made social systems adaptable to migration and the existence of alternative political and economic possibilities an important factor for the existence of free and unfree labor. ${ }^{53}$

Interregional and intercontinental trade is necessary for the emergence of commodified labor, as explained above, allowing for local and regional trade in societies dominated by reciprocal labor. The rapid expansion of intercontinental trade in the second half of the nineteenth century was built on earlier international commodity trade - such as the trade in gold, pepper, amber, bee wax, rice and, more importantly, ivory - internal trading networks in Sub-Saharan Africa, and the trans-

but withdrawing from state and market interference by focusing on self-sufficient agricultural production.

${ }^{53}$ Vaughan, "Africa and the Birth of the Modern World," 154, referring to the work of Frederick Cooper and Gareth Austin, see for example, Cooper, “African Labor History,” 96. As an example of self-organizing clusters without political centralization, Gareth Austin refers to the work of archeologists on urbanization without political centralization in the Middle Niger area, Austin, "Reciprocal Comparison," 13. 
Saharan trade and its implications for labor. ${ }^{54}$ An intriguing aspect of internal trade in Africa is the limitations imposed by environmental reasons. Where water transport via rivers and lakes was impossible, men had to carry out all the hauling work themselves as horses, mules and the like could not survive due to their proneness to diseases, similar to other tropical parts of the world. Before 1900, such circumstances obviously imposed serious interruptions on the production of bulky goods and long-term trade in bulky goods in comparison to areas of other large continents with more moderate and colder weather conditions. ${ }^{55}$

The most important traditional African commodities - which provide historical evidence of specialization, markets and, consequently, commodified labor - are salt, iron, copper and gold, much later also diamonds, ivory and the large-scale exchange between pastoralists and agriculturalists. ${ }^{56}$ And of course slaves. Slave trade from northeast Africa, and especially Ethiopia, to the Arabian Peninsula and India testifies

\footnotetext{
${ }^{54}$ On the produce of commodities for international markets in pre-colonial Africa and in the nineteenth century, see among others: David Eltis, "The Relative Importance of Slaves and Commodities in the Atlantic Trade of Seventeenth-Century Africa," Journal of African History 35-2 (1994), 237-249. David Eltis, "The Slave Trade and Commercial Agriculture in an African Context," in: Robin Law, Suzanne Schwarz and Silke Strickrodt (eds.), Commercial Agriculture, the Slave Trade \& Slavery in Atlantic Africa (Woodbridge, Suffolk: James Currey, 2013), 28-53. Robin Law (ed.), From Slave Trade to "Legitimate" Commerce; Walter Hawthorne, Planting Rice and Harvesting Slaves: Transformations Along the Guinea-Bissau Coast, 1400-1900) (Portsmouth NH: Heinemann, 2003); JanGeorg Deutsch, Emancipation Without Abolition in German East Africa, c. 1884-1914 (Oxford: James Currey, 2006). For the growth of wage labor during the colonial and early post-colonial period see: John Sender and Sheila Smith, The Development of Capitalism in Africa (London: Taylor \& Francis, 1986).

${ }^{55}$ See the contribution by Karin Pallaver.

${ }^{56}$ On pre-colonial labor and markets, see: Catherine Coquery-Vidrovitch and Paul E. Lovejoy (eds.), The Workers of African Trade (Beverly Hills: Sage, 1985).
} 
to the existence of international and even intercontinental slave trade before the massive Atlantic slave trade. ${ }^{57}$ This started already in the late Middle Ages and was continued by the Omanis, the Portuguese and eventually other European trade companies. ${ }^{58}$ In addition to these traditional exports of slaves from the Savanna and the Horn of Africa - estimated at an annual average of 10,000 by Patrick Manningthere was the export of slaves from the West Coast, rising quickly in the eighteenth century to 100,000 per year, whereas the number of slaves exported from East Africa saw its peak a few decades later. ${ }^{59}$

The main question that arises from this is to what extent commodified free labor occurred before and during the rise of the slave trade. Recently, the history and time-depth of urbanization in Sub-Saharan West Africa has been greatly revised. However, because of lack of detailed historical evidence, the occurrence of commodified free labor - in the form of wage labor or in the form of small holders, producing commercial crops for the market - is difficult to establish for this period. ${ }^{60}$

\footnotetext{
${ }^{57}$ Richard M. Eaton, “The Rise and Fall of Military Slavery in the Deccan, 1450-1650," in: Indrani Chatterjee and Richard M. Eaton (eds.) Slavery and South Asian History (Bloomington: Indiana University Press 2006), 115-135.

${ }^{58}$ See the contribution by Karin Pallaver.

${ }^{59}$ Manning, Slavery and African Life, 18. David Eltis, "Was Abolition of the American and British Slave Trade Significant in the Broader Atlantic Context?," in: Marcel van der Linden (ed.), Humanitarian Intervention and Changing Labor Relations. The Long-Term Consequences of the Abolition of the Slave Trade (Leiden: Brill, 2011), 117-139.

${ }^{60}$ Jan Lucassen, "Free and Unfree Labour before the Twentieth Century: A Brief Overview," in: Marcel van der Linden (ed.), Humanitarian Intervention and Changing Labor Relations. The Long-Term Consequences of the Abolition of the Slave Trade (Leiden: Brill, 2011), 45-56, 52.
} 
The amendments of the Nieboer-Domar thesis by André Köbben may provide a useful point of departure here. ${ }^{61}$ According to Köbben, open resources, which form the main point of Nieboer's argument, are not sufficient to explain the emergence of slave labor in a society. It also should be stratified. In Köbben's words: "Slavery is a form of systematic coercion. Such coercion seems hardly feasible in egalitarian societies, i.e. societies in which only individual, non-hereditary differences of prestige and power are present." ${ }^{\prime 2}$ That is to say that slavery only occurred where two or more hereditary classes unequal in status and power existed, which was the case in many societies in Africa.

Given the cases of early urbanization, the question is not if, but to what extent, where and when free commodified labor relations, for example in the form of small holders, occurred before the nineteenth century, alongside reciprocal and tributary labor and of course unfree commodified labor. For example, Bosman describes the fishermen of the Gold Coast c. 1700 as independent producers. As soon as international exportation of slaves expanded, slavery may have spread, converting both reciprocal and independent labor into slave labor and leaving less room for free wage labor - which would have existed predominantly as occasional rather than regular labor - especially in the tropical and Savanna parts of Africa. The numerous descriptions of pre-colonial polities in Sub-Saharan Africa seem to prove this.

\footnotetext{
${ }^{61}$ André Köbben, "Why Slavery?," in: Tom Brass and Marcel van der Linden (eds.), Free and Unfree Labour. The Debate Continues (Bern: Peter Lang 1997), 77-90.

${ }^{62}$ Köbben, "Why Slavery?," 84; Herman Jeremias Nieboer, Slavery as an Industrial System: Ethological Research (The Hague: Martinus Nijhoff, 1900); Evsey D. Domar “The Causes of Slavery and Serfdom: A Hypothesis," The Journal of Economic History 30-1 (1945), 18-32. For a revision, see: Erik Green, "The Economics of Slavery in the Eighteenth-Century Cape Colony: Revising the NieboerDomar Hypothesis," International Review of Social History 59-1 (2014) DOI http://dx.doi.org/10.1017/S0020859013000667
} 
The authors of this volume have been struggling with the difficult task of determining whether the societies at hand were commodified or not. As suggested by Paul Lane, commodified labor was rare in Tanzania from 1500 to the mid-nineteenth century. Merchants and tradesmen, self-employed artisans and craft workers, fishermen and slaves - either domestic slaves or plantation slaves - who worked primarily for the market formed a small part of the total population. They lived mostly in the coastal area, perhaps making up some 1 to 5 percent of the total population. Reciprocal laborers working for the household, especially in subsistence farming and herding activities, formed approximately 75 to 85 percent of the total population, while exchanging some of their surplus production on the market. Another small part of the population performed redistributive tasks - administrative and juro-political tasks but also specialized craft production, such as smelting and blacksmithing - for the community. Tributary slave and obligatory labor was performed for the ruling elites, in some cases full time (perhaps some 10 percent) and in most other cases as a secondary labor relation. Karin Pallaver shows how in the nineteenth century growing demand for ivory and for slave laborers for the clove plantations in Zanzibar changed labor relations from less reciprocal to more commodified labor. Traders, backed by the Omani state and financed by Indian capital penetrated the inlands of Tanzania, while on the other hand African businessmen from the interior started regional trading to the coast. As a consequence, a new class of commodified workers developed: porters, a peculiar case of wage labor in pre-colonial Africa, as Karin Pallaver shows. ${ }^{63}$ For the 1900 cross-section, the colonization of Tanzania brought about another class of commodified workers: forced wage workers in the railway construction and on the settlers plantations. Still, even in 1950, reciprocal agricultural labor was still the dominant labor relation, while commodified labor relations were

\footnotetext{
${ }^{63}$ See also: Stephen Rockel, Carriers of Culture: Labor on the Road in Nineteenth Century East Africa (Portsmouth NH: Heinemann, 2006).
} 
often combined with other labor relations. For the 2000 cross-section, the census takers marked the majority of the population as self-employed workers. Jelmer Vos shows how in 1800, in what is now called Angola, the majority of the population worked under reciprocal labor relations, and that outside the Portuguese colonial sphere slaves were generally not commodified. After the end of the Atlantic slave trade, the Angolan economy rapidly commercialized. More people shifted from reciprocal labor to commodified labor as the production of export crops demanded extra labor, often in the form of slave labor. Still, this process only applied to a relatively small part of the total population. In 1900, almost half of the population still worked in reciprocal forms of agriculture; only by 1950, the number of wage workers in the private sector had increased significantly, as well as the number of independent farmers. By 2000, as a result of the collapse of the formal economy, the number of salaried jobs in private enterprises declined. Wage work only increased in non-market institutions; while work in the informal sector led to a rising number of self-employed workers, especially in the cities. In the countryside, many of the independent workers had disappeared and self-subsistence agriculture was predominant.

Rory Pilossof shows that around 1900 in present day Zimbabwe, selfsufficiency and concomitant reciprocal labor also still prevailed. From 1900 to 1950, the number of wage workers increased from 5 percent to 25 percent, and they mainly worked in agriculture and forestry but also in domestic service, mining, and manufacturing, though this was often combined with reciprocal labor relations in agriculture. In 2002, the number of wage workers dropped to 14 percent, and subsistence agriculture remained a key labor relation in Zimbabwe throughout the nineteenth and twentieth century. 
In sum, the application of reciprocal comparison as part of a new methodology to integrate African Labor into Global Labor History has led to the development of a taxonomy of labor relations, fed by the input from both Africanists and labor history specialists from other areas. This taxonomy makes it possible not only to compare but also to connect developments in labor history worldwide. The case studies described in this special section show us that the focus on Sub-Saharan Africa has led to an increased awareness regarding the gendered division of labor worldwide. These case studies also demonstrate the durability of reciprocal labor, often in combination with other types of labor, such as self-employment. This combination can also be detected in other parts of the world. In the twenty-first century, we even witness an increase of this worldwide in the form of an increase in precarious work and an increase in what is often called-the informal sector. Finally, the taxonomy can help us interconnect, on the one hand, the shifts between free and unfree labor connected to slavery, the slave trade and the abolition of slavery in Sub-Saharan Africa with on the other hand, the shifts in labor relations elsewhere in the world.

\section{APPENDIX: Definitions of Labor Relations}

\section{Not working}

1. Incapable: People who cannot work, because they are too young $(<6$ years) or too old or too handicapped

2. Affluent: People are so prosperous that they don't have to work for a living (rentiers, etc.)

\section{Working within a Household}


3. Leading household producers: heads of self-sufficient households ${ }^{64}$

4. Household kin producers: subordinate kin (men, women, children) contributing to the maintenance of self-sufficient households

5. Household servants: subordinate non-kin (slaves, serfs) contributing to the maintenance of self-sufficient households

\section{Working within a Community}

6. Community-based redistribution agents: People who perform tasks for the local community in exchange for communally provided remuneration in kind, i.e., services or goods like food or a plot and seed to produce it themselves. This includes, for example, the Indian jajmani system.

\section{Working for Non-Market Institutions (Public Authorities, Clerical Hierarchies, NGOs, etc.)}

7. Public forced laborers: People who work for non-market institutions, and are remunerated mainly in kind, e.g., corvée laborers; conscripted soldiers and sailors, convicts.

8. Public wage earners: Wage earners who produce goods or services for nonmarket institutions (e.g., public authorities, non-commercial hospitals, etc.) in exchange for mainly monetary remuneration (including temporary unemployed)

8.1. Sharecropping public wage earners: Remuneration is a fixed share in the total output (including temporary unemployed)

8.2. Piece-rate public wage earners: Remuneration at piece rates (including temporary unemployed)

8.3. Time-rate public wage earners: Remuneration at time rates (including temporary unemployed)

9. Public indentured laborers: People under contract to work as unfree laborers for a non-market institution for a specific period of time to pay off a debt

\footnotetext{
${ }^{64}$ Households include family-based and non-kin-based forms like monasteries, palaces, etc.
} 
10.Public serfs: People working for non-market institutions and who are bound to the soil and on call for specific tasks for a maximum number of days

11.Public slaves: People who are owned by and work for non-market institutions indefinitely (deprived of the right to leave, to refuse to work, or to receive compensation in return for their labor)

\section{Working for Market Institutions (Commercial Enterprises)}

12. Self-employed: People who produce goods or services for market institutions, possibly in co-operation with other household members or no more than three wage laborers, apprentices, serfs or slaves (e.g., peasants, craftsmen, petty traders, transporters, as well as people in the professions $)^{65}$

13. Employers: People who produce goods or services for market institutions by employing more than three wage laborers, indentured laborers, serfs or slaves

14. Market wage earners: Wage earners who produce commodities or services for the market in exchange for mainly monetary remuneration

14.1. Sharecropping wage earners: Remuneration is a fixed share in the total output (including temporary unemployed)

14.2. Piece-rate wage earners: Remuneration at piece rates (including temporary unemployed)

14.3. Time-rate wage earners: Remuneration at time rates (including temporary unemployed)

15.Indentured market laborers: People under contract to work as unfree laborers for an employer for a specific amount of time to pay off a debt

16. Servile market workers: People who are bound to the soil and on call for specific tasks for a maximum number of days, producing for the market

17. Chattel slaves: People who are owned by their employers (masters) indefinitely (deprived of the right to leave, to refuse to work, or to

\footnotetext{
${ }^{65}$ All the members of a family working in a putting-out system should be counted as separate selfemployed producers.
} 
receive compensation in return for their labor) and who produce goods or services for the market.

\section{References}

Allen, Richard C., Slaves, Freedmen, and Indentured Laborers in Colonial Mauritius (Cambridge: Cambridge University Press, 2006).

Alpers, Edward A., Ivory \& Slaves in East Central Africa (London: Heinemann, 1975).

Austin, Gareth, Labour, Land and Capital in Ghana: From Slavery to Free Labour in Asante, 1807-1956 (Rochester: University of Rochester Press, 2005).

------, "Reciprocal Comparison and African History: Tackling Conceptual Eurocentrism in the Study of Africa's Economic Past," African Studies Review 50-3 (2007), 1-28.

-----, “The 'Reversal of Fortune' Thesis and the Compression of History: Perspectives from African and Comparative Economic History," Journal of International Development 20-8 (2008), 996-1027.

-----, "Cash Crops and Freedom: Export Agriculture and the Decline of Slavery in Colonial West Africa," International Review of Social History 54-1 (2009), 1-37.

Austen, Ralph A., "The Trans-Saharan Slave Trade: A Tentative Census," in: Henry A. Gemery and Jan S. Hogendorn (eds.), The Uncommon Market; Essays in the Economic History of the Atlantic Slave Trade (New York: Academic Press, 1979), 77-106. -----, "The 19th Century Islamic Slave Trade from East Africa (Swahili and Red Sea Coasts): A Tentative Census," Slavery and Abolition: A Journal of Slave and PostSlave Studies 9-3 (1988), 21-44.

-----, "The Mediterranean Islamic Slave Trade out of Africa: A Tentative Census," in: Elizabeth Savage (ed.), The Human Commodity: Perspectives on the TransSabaran Slave Trade (London: Frank Cass, 1992), 214-224. 
Bergad, Laird W., Slavery and the Demographic and Economic History of Minas Gerais, Brazil, 1720-1888 (Cambridge: Cambridge University Press, 1999).

Bonner, Philip, Jonathan Hyslop and Lucien van der Walt, "Rethinking Worlds of Labour: Southern African Labour History in International Context," African Studies 6-2/3 (2007), 137-168.

Boserup, Ester, Women's Role in Economic Development (London: Earthscan, 2007).

Bosman, Willem, A New and Accurate Description of the Coast of Guinea, Divided into the Gold, the Slave, and the Ivory Coasts (London: J.P. Knapton, 1705).

Campbell, Gwyn R. (ed.), The Structure of Slavery in Indian Ocean Africa and Asia (London: Frank Cass, 2004).

Chatterjee, Indrani, and Richard M. Eaton (eds.) Slavery and South Asian History (Bloomington: Indiana University Press 2006).

Cohen, Gerald A., Karl Marx's Theory of History: A Defence (Oxford: Oxford University Press, 1978).

Cooper, Frederick, "Back to Work: Categories, Boundaries and Connections in the Study of Labour," in: Peter Alexander and Rick Halpern (eds.), Racializing Class, Classifying Race (London: Macmillan, 2000), 213-235.

------, "What is the Concept of Globalization Good For? An African Historian's Perspective," African Affairs 100 (2001), 193-213.

-----, “African Labor History," in: Jan Lucassen (ed.), Global Labour History. A State of the Art (Bern: Peter Lang, 2006), 91-116.

Coquery-Vidrovitch, Catherine, and Paul E. Lovejoy (eds.), The Workers of African Trade (Beverly Hills: Sage, 1985).

Curtin, Philip D., The Atlantic Slave Trade: A Census (Madison WI: University of Wisconsin, 1969).

Curto, José C., and Renée Soulodre-La France (eds.), Africa and the Americas: Interconnections during the Slave Trade (Trenton: Africa World Press, 2005). 
Deutsch, Jan-Georg, Emancipation Without Abolition in German East Africa, c. 1884-1914 (Oxford: James Currey, 2006).

Domar, Evsey D., "The Causes of Slavery and Serfdom: A Hypothesis," The Journal of Economic History 30-1 (1945), 18-32.

Eaton, Richard M., "The Rise and Fall of Military Slavery in the Deccan, 14501650," in: Indrani Chatterjee and Richard M. Eaton (eds.) Slavery and South Asian History (Bloomington: Indiana University Press 2006), 115-135.

Eltis, David, "The Relative Importance of Slaves and Commodities in the Atlantic Trade of Seventeenth-Century Africa," Journal of African History 35-2 (1994), 237-249.

-----, "Was Abolition of the American and British Slave Trade Significant in the Broader Atlantic Context?," in: Marcel van der Linden (ed.), Humanitarian Intervention and Changing Labor Relations. The Long-Term Consequences of the Abolition of the Slave Trade (Leiden: Brill, 2011), 117-139.

-----, "The Slave Trade and Commercial Agriculture in an African Context," in: Robin Law, Suzanne Schwarz and Silke Strickrodt (eds.), Commercial Agriculture, the Slave Trade \& Slavery in Atlantic Africa (Woodbridge, Suffolk: James Currey, 2013), 28 53.

-----, Frank D. Lewis and David Richardson, "Slave Prices, the African Slave Trade and Productivity in the Caribbean, 1674-1807," Economic History Review 584 (2005), 673-700.

-----, Stephen D. Behrendt, David Richardson and Herbert S. Klein, The Transatlantic Slave Trade 1527-1867: A Database on CD-Rom (New York: Cambridge University Press, 1999).

-----, and David Richardson (eds.), Extending the Frontiers: Essays on the New Transatlantic Slave Trade Database (New Haven: Yale University Press, 2008). -----, and ------, Atlas of the Transatlantic Slave Trade (New Haven CT: Yale University Press, 2010). 
Fall, Babacar, Le travail forcé en Afrique-Occidentale française, 1900-1946 (Paris: Karthala, 1993).

Florentino, Manolo, “The Slave Trade, Colonial Market, and Slave Families in Rio de Janeiro, ca. 1790-ca. 1830," in: David Eltis and David Richardson (eds.), Extending the Frontiers: Essays in the New Transatlantic Slave Trade Database (New Haven: Yale University Press, 2008), 275-312.

Freund, Bill, The African Worker (Cambridge: Cambridge University Press, 1988).

------, "Labour Studies and Labour History in South Africa: Perspectives from the Apartheid Era and After," International Review of Social History 58-3 (2013), 493519.

Galenson, David W., Traders, Planters, and Slaves: Market Behavior in Early English America (Cambridge: Cambridge University Press, 1986).

Green, Erik, "The Economics of Slavery in the Eighteenth-Century Cape Colony: Revising the Nieboer-Domar Hypothesis," International Review of Social History 59-1 (2014) DOI http://dx.doi.org/10.1017/S0020859013000667

Guha, Amalendu, "The Medieval Economy of Assam," in: Tapan Raychaudhuri and Irfan Habib (eds.), The Cambridge Economic History of India, volume 1: $c$. 1200 - c. 1750 (Cambridge: Cambridge University Press, 1982), PLEASE ADD

\section{PAGE NUMBERS.}

Hawthorne, Walter, Planting Rice and Harvesting Slaves: Transformations Along the Guinea-Bissau Coast, 1400-1900) (Portsmouth NH: Heinemann, 2003).

Hayami, Akira, Osamu Saitô and Ronald P. Toby (eds.), The Economic History of Japan, 1600-1990, volume 1: Emergence of Economic Society in Japan, 1600-1859 (Oxford: Oxford University Press, 2004).

Heywood, Linda M. (ed.), Central Africans and Cultural Transformations in the American Diaspora (Cambridge: Cambridge University Press, 2002). 
Hirschman, Albert O., Exit, Voice, and Loyalty: Responses to Decline in Firms, Organizations, and States (Cambridge MA: Harvard University Press, 1970).

Hofmeester, Karin, and Christine Moll-Murata (eds.), International Review of Social History 56-1 (2011) (Special Issue: “The Joy and Pain of Work: Global Attitudes and Valuations, 1500-1650”).

Hopkins, Anthony G., “The Lagos Strike of 1897: An Exploration in Nigerian Labour History," Past and Present 35 (1966), 133-155.

------, An Economic History of West Africa (London: Longman 1973).

Inikori, Joseph E., and Stanley L. Engerman (eds.), The Atlantic Slave Trade: Effects on Economies, Societies, and Peoples in Africa, the Americas, and Europe (Durham: Duke University Press, 1992).

------, Africans and the Industrial Revolution in England: A Study in International Trade and Development (Cambridge: Cambridge University Press, 2002).

------, "The Economic Impact of the 1807 British Abolition of the Transatlantic Slave Trade," in: Toyin Falola and Matt D. Childs (eds.), The Changing Worlds of Atlantic Africa: Essays in Honor of Robin Law (Durham: Carolina Academic Press, 2009), 163-182.

Jerven, Morten, Gareth Austin, Erik Green, Chibuike Uche, Ewout Frankema, Johan Fourie, Joseph E. Inikori, Alexander Moradi and Ellen Hillbom, "Moving Forward in African Economic History: Bridging the Gap Between Methods and Sources," African Economic History Working Paper Series 1 (2012), see: http://www.aehnetwork.org/wp-content/uploads/2012/05/AEHN-WP-1.pdf

Köbben, André, "Why Slavery?,” in: Tom Brass and Marcel van der Linden (eds.), Free and Unfree Labour. The Debate Continues (Bern: Peter Lang 1997), 77-90.

Kok, Jan, “The Family Factor in Migration Decisions," in: Jan Lucassen, Leo Lucassen and Patrick Manning (eds.), Migration History in World History. Multidisciplinary Approaches (Leiden: Brill, 2011), 215-250. 
Law, Robin (ed.), From Slave Trade to "Legitimate" Commerce. The Commercial Transition in Nineteenth-Century West Africa (Cambridge: Cambridge University Press, 1995).

Lovejoy, Paul E., and David Richardson, “The Business of Slaving: Pawnship in Western Africa, c. 1600-1810," The Journal of African History 42-1 (2001), 67-89. Lovejoy, Paul E., and Toyin Falola (eds.), Pawnship, Slavery, and Colonialism in Africa (Trenton NJ: Africa World Press, 2003).

Likaka, Osumaka, Rural Society and Cotton in Colonial Zaire (Madison WI: University of Wisconsin Press, 1997).

Lis, Catharina, and Hugo Soly, Worthy Efforts: Attitudes to Work and Workers in Pre-Industrial Europe (Leiden: Brill, 2012).

Lovejoy, Paul E., Transformations in Slavery: A History of Slavery in Africa (Cambridge: Cambridge University Press, 2013).

Lucassen, Jan, "Free and Unfree Labour before the Twentieth Century: A Brief Overview," in: Marcel van der Linden (ed.), Humanitarian Intervention and Changing Labor Relations. The Long-Term Consequences of the Abolition of the Slave Trade (Leiden: Brill, 2011), 45-56.

------, Outlines of a History of Labour (IISH Research Papers 51, 2013), also available at http://socialhistory.org/en/publications/outlines-history-labour.

Mandala, Elias, "Capitalism, Kinship and Gender in the Lower Tchiri (Shire) Valley of Malawi, 1860-1960: An Alternative Theoretical Framework," African Economic History 13 (1984), 137-169.

Manning, Patrick, Slavery and African Life: Occidental, Oriental, and African Slave Trades (New York: Cambridge University Press, 1990).

Miers, Suzanne, and Richard Roberts (eds.), The End of Slavery in Africa (Madison WI: Wisconsin University Press, 1988). 
Miers, Suzanne, and Martin A. Klein (eds.), Slavery and Colonial Rule in Africa (London: Frank Cass, 1999).

Miller, Joseph C., "Capitalism and Slaving: The Financial and Commercial Organization of the Angolan Slave Trade, According to the Accounts of Antonio Coelho Guerreiro (1684-1692)," The International Journal of African Historical Studies 171 (1984), 1-56.

-----, Way of Death. Merchant Capitalism and the Angolan Slave Trade, 1730-1830 (Madison WI: University of Wisconsin Press, 1988).

Nieboer, Herman Jeremias, Slavery as an Industrial System: Ethological Research (The Hague: Martinus Nijhoff, 1900).

Northrup, David, Beyond the Bend in the River: African Labor in Eastern Zaire, 1865-1940 (Athens OH: Ohio University Center of International Studies, 1988).

Nunn, Nathan, "Historical Legacies: A Model Linking Africa’s Past to its Current Underdevelopment," Journal of Development Studies 83-1 (2007), 157-175.

-----, “The Long Term Effects of Africa's Slave Trades," Quarterly Journal of Economics 123-1 (2008), 139-176.

O'Brien, Patrick, "European Economic Development: the Contribution of the Periphery," Economic History Review 35-1 (1982), 1-18.

O’Rourke, Kevin H., Leandro Prados de la Escosura and Guillame Daudin, “Trade and Empire," in: Stephen Broadberry and Kevin H. O'Rourke (eds.), The Cambridge Economic History of Modern Europe, volume, 1700-1870 (Cambridge: Cambridge University Press, 2010), 96-121.

Penvenne, Jeanne, African Workers and Colonial Racism: Mozambican Strategies and Struggles in Lourenço Marques, 1877-1962 (Portsmouth NH: Heinemann, 1995).

Phimister, Ian, Wangi Kolia: Coal, Capital, and Labour in Colonial Zimbabwe, 18941954 (Harare: Baobab Books, 1994). 
Rockel, Stephen, Carriers of Culture: Labor on the Road in Nineteenth Century East Africa (Portsmouth NH: Heinemann, 2006).

Rodney, Walter, "Gold and Slaves on the Gold Coast, " Transactions of the Historical Society of Ghana 10 (1969), 13-28.

-----, How Europe Underdeveloped Africa (Washington: Howard University Press, 1974).

Schler, Lynn, Louise Bethlehem and Galia Sabar, "Rethinking Labour in Africa, Past and Present," African Identities 7-3 (2007), 287-298.

Sender, John, and Sheila Smith, The Development of Capitalism in Africa (London: Taylor \& Francis, 1986).

Sombart, Werner, Das Proletariat. Bilder und Studien (Frankfurt am Main: Rütten \& Loening, 1906).

Tilly, Charles, "Demographic Origins of the European Proletariat," in: David Levine (ed.), Proletarianization and Family History (Orlando: Academic Press 1984), 1-85.

-----, and Chris Tilly, Work under Capitalism (Boulder CO: Westview Press, 1998).

Van der Linden, Marcel, Workers of the World. Essays toward a Global Labor History (Leiden: Brill, 2008).

Van Onselen, Charles, Chibaro: African Mine Labour in Southern Rhodesia, 19001933 (London: Pluto Press, 1976).

-----, The Seed is Mine: the Life of Kas Maine, a South African Sharecropper, 1894 1985 (New York: Hill and Wang, 1996).

Vaughan, Megan, "Africa and the Birth of the Modern World," Transactions of the Royal Historical Society, Sixth Series 16 (2006), 143-162.

Voyages: The Trans-Atlantic Slave Trade Database: http://www.slavevoyages.org.

Williams, Eric, Capitalism and Slavery (Chapel Hill: University of North Carolina Press, 1994 [1944]). 